\title{
Unconstitutional constitutional amendment or constitutional dismemberment? A reappraisal of the presidential term limit amendment in Cameroon
}

\author{
Laura-Stella Enonchong (iD \\ De Montfort University, Gateway House, Leicester LE1 9BH, United Kingdom \\ Email: laura.enonchong@dmu.ac.uk
}

\begin{abstract}
Presidential term limit provisions are often perceived as a feature of modern democratic systems. It has been argued that their existence is a key intervention mechanism to pre-empt some undemocratic outcomes associated with incumbency advantages. In 2008, the Constitution of Cameroon was amended to abolish the presidential term limit. More than ten years on, there are ostensible signs of a democratic decline. This article takes a retrospective look at the constitutional amendment to assess its constitutionality. It is argued that a conclusion on the constitutionality of the amendment may not be unequivocal. Nevertheless, there are substantial grounds for considering the constitutional change as a constitutional dismemberment. This is premised on the fact that, although the amendment followed the normal rules for constitutional amendments, the transformation amounted to a fundamental break with the constitutional commitment to democracy that underpinned the adoption of the 1996 Constitution.
\end{abstract}

Keywords: Cameroon; presidential term limit provisions; incumbency advantage; constitutional dismemberment; constitutional amendment

\section{Introduction}

In the years following the Arab Spring of 2010 there was a reawakening of the issue of term limits. More recently, with a growing list of long-term presidents winning re-election, the time seems propitious to be discussing term limits, as it has become an issue for interminable debate. ${ }^{1}$ Presidential term limits have become a key feature in defining democracy, and consequently one that many political systems purportedly adopt to promote democratic governance. Historically, the concept of limited tenure dates back

\footnotetext{
${ }^{1}$ Julia Grauvogel and Charlotte Heyl, 'The Study of Term Limits in Sub-Saharan Africa: Lessons on Democratisation and Autocratisation' (2021) 55(3) Africa Spectrum 215, 216.

(C) The Author(s), 2022. Published by Cambridge University Press. This is an Open Access article, distributed under the terms of the Creative Commons Attribution licence (http://creativecommons.org/licenses/by/4.0), which permits unrestricted re-use, distribution and reproduction, provided the original article is properly cited.
} 
to ancient democracies in Athens and Rome. ${ }^{2}$ It found its modern expression in the mid-nineteenth century and gradually spread throughout the world. Within Sub-Saharan Africa, the concept gained prominence in the 1990s as an upshot of the 'third wave of democratization'. ${ }^{3}$ A majority of the sub-Saharan African constitutions adopted in the 1990s contained provisions introducing a two-term limit to presidential tenure. ${ }^{4}$ In spite of its ubiquity, the challenge has been its enforcement both within Africa and beyond. Recent evidence demonstrates a trend towards contravention of term limits through constitutional amendments eliminating them, ${ }^{5}$ or simply by presidents 'outstaying their welcome'. ${ }^{6}$ In Africa in 2020, at least four incumbent presidents contravened term limits, confirming a disturbing trend in Africa. ${ }^{7}$ The increasing phenomenon of contravention has weakened democratic consolidation by promoting the vices associated with incumbency advantages and the perpetuation of arbitrariness due to long terms in power. Prolongation or elimination of term limits precipitated a coup d'état in Honduras between 2009 and 2010, in Togo in 2018 and in Niger in 2010. ${ }^{8}$ In other less dramatic circumstances, it has ensured life presidencies, thereby constraining political party rotation. In Guinea, a 2001 referendum saw the elimination of presidential term limits, allowing President Lasana Conté to remain in office until his death in 2008. Similarly, a constitutional amendment in Togo provided the basis for President Gnassingbé Eyadéma to run for a third term, winning elections and staying in power until his death in 2005. Other more pro-democratic societies with obdurate opposition parties, such as in Malawi, ${ }^{9}$ Zambia $^{10}$ and Nigeria, ${ }^{11}$ resisted attempts by serving presidents to extend or eliminate term limits. Further afield and more recently, the courts in some countries such as Honduras have become complicit in eliminating presidential term limits even where such provisions are entrenched against amendment. ${ }^{12}$ On a more optimistic note, in 2018

\footnotetext{
${ }^{2}$ Tom Ginsburg, James Melton and Zachary Elkins 'On the Evasion of Executive Term Limits' (2011) 52 William and Mary Law Review 1806, 1818. Although it is acknowledged that there have been uncodified term limits that have risen to the level of constitutional conventions, these will not be discussed here, as they are not the focus of this contribution.

${ }^{3}$ Samuel Huntington, The Third Wave: Democratisation in the Late 20th Century (University of Oklahoma Press, Norman, OK, 1991).

${ }^{4}$ Christina Murray and Micha Wiebusch, 'Presidential Term Limits and the African Union' (2019) 63 (S1) Journal of African Law 131, 134.

${ }^{5}$ Gideon Maltz states that between 1992 and 2006, 26 presidents contravened their term limits. Gideon Maltz, 'The Case for Presidential term Limits' (2007) 18(1) Journal of Democracy 128.

${ }^{6}$ Bruce Baker, 'Outstaying One's Welcome: The Presidential Third Term Debate in Africa' (2002) 8(4) Contemporary Politics 285.

${ }^{7}$ The incumbents included Presidents Alpha Condé of Guinea, Idriss Déby of Chad, Patrice Talon of Benin and Yoweri Museveni of Uganda. See Joseph Siegle, 'The Erosion of Term Limits in Africa Reflects Worrying Trend' (Africa Centre for Strategic Studies, February 2021). Available at: <https://africacenter.org/spotlight/ erosion-term-limits-africa-reflects-worrying-trend>.

${ }^{8}$ Virginie Baudais and Grégory Chauzal, 'The 2010 Coup d'etat in Niger: A Praetorian Regulation of Politics' (2010) 110(439) African Affairs 295.

${ }^{9}$ Peter VonDoepp, 'The Politics of Presidential Term Limits in Malawi' in Alexander Baturo and Robert Elgie (eds), The Politics of Presidential Term Limits (Oxford University Press, Oxford, 2019) 291-309.

${ }^{10}$ Cephas Lumina, 'Frederick Chiluba's Third Presidential Term Bid in Zambia' in Jack Mangal (ed), The Politics of Challenging Presidential Term Limits in Africa (Palgrave Macmillan, New York, 2020) 205-26.

${ }^{11}$ Hassan Saliu and Abdulrasheed Mohhamad, 'Failed Elongation of Presidential Term Limits in Nigeria Under Olusegun Obasanjo' in Jack Mangal (ed), The Politics of Challenging Presidential Term Limits in Africa (Palgrave Macmillan 2020) 171-203.

${ }^{12}$ David Landau and Brian Sheppard, 'The Honduran Constitutional Chamber's Decision Erasing Presidential Term Limits: Abusive Constitutionalism by Judiciary?' (2015) International Journal of
} 
Chad's new Constitution reinstated a two-term limit provision that had been eliminated in 2005. ${ }^{13}$ In other countries, including Ghana, Kenya and Liberia, presidents have consistently respected term limit provisions. Nevertheless, the more regressive trend towards elimination of term limits highlights the subtle and covert ways in which 'longserving and powerful' presidents are extending their grip on power. ${ }^{14}$

Regardless of the regressive trend, the merits of presidential term limits cannot be discounted, particularly in political regimes described by Baker as electoral authoritarian regimes. According to Gideon Maltz, such regimes pose the greatest threat to the institution of term limits, the imposition and respect for which provide enormous potential for democratization. ${ }^{15}$ Given their potential value in such regimes, constitutional transformations intended for their elimination can have significant consequences for the essential commitments embodied in a constitution or its fundamental principles, identity or human rights commitments. In that respect, they may destroy or repeal the essential protection provided by the constitution in ways that presage regressive trends in democratic governance. In other words, in some countries presidential term limits constitute an essential feature of a constitution or its core commitment(s). Elimination of that feature through constitutional change may gradually lead to the erosion of that core commitment. Where that occurs, the constitutional amendment is more appropriately understood as a 'dismemberment' due to the effect it has on that core feature of the constitution.

In 2008, Cameroon joined the countries listed previously to eliminate presidential term limits, which would have seen the end of President Paul Biya's term in office in 2011. This move was highly controversial and openly opposed by the population. More than ten years on, President Biya still retains power with an increasing prospect of a life presidency. The main purpose of this article is to reassess the nature of the constitutional amendment of the term limit provisions in the light of subsequent tenuous political developments and an ostensible democratic decline in Cameroon. First, the article assesses whether the amendment was constitutional. It argues that the constitutionality of the amendment is not unequivocal, but can at best be perceived as undemocratic. Second, it is contended that the change can be more appropriately characterized as a constitutional dismemberment, given the nature of its effects on the essential constitutional commitment to democracy, as shown by subsequent political developments in Cameroon.

After this introduction, the article proceeds with a discussion of the background to the adoption of the legislative provision eliminating the presidential term limit. That is followed by an analysis of the constitutionality of the amendment. The article next discusses the concept of constitutional dismemberment and contextualizes that with particular reference to the democratic decline in Cameroon subsequent to the term limit transformation. That discussion is followed by broad reflections on the normative framework for constitutional amendments in Cameroon, informed by comparative approaches.

\section{Background}

The presidential term limit in Cameroon is regulated by article 6(2) of the 1996 Constitution. That provision was introduced in 1996 as an amendment to the 1972

\footnotetext{
Constitutional Law Blog. Available at: <http://www.iconnectblog.com/2015/05/the-honduran-constitu tional-chambers-decision-erasing-presidential-term-limits-abusive-constitutionalism-by-judiciary >

${ }^{13}$ Constitution of Chad, art. 66.

${ }^{14}$ David Landau and Yaniv Roznai, 'Term Limits and the Unconstitutional Constitutional Amendment Doctrine' in Alexander Baturo and Robert Elgie (eds), The Politics of Presidential Term Limits (Oxford University Press, Oxford, 2019) 53-72.

${ }^{15}$ Maltz, 'The Case for Presidential Term Limits' 130.
} 
Constitution, under which the applicable presidential term was five years with no specific term limits. Reluctantly acceding to domestic pressure and in a bid to mirror the prevalent trend of the third wave of democratization, the 1972 Constitution was substantially amended by parliament on the 'initiative' of the president. With regard to the presidential term, the 1996 amendment extended it from five to seven years and introduced a twoterm limit. Two presidential elections were subsequently organized in 1997 and 2004 with the incumbent winning what was described as a tainted victory in both instances. ${ }^{16}$ The implication of the term limit provision was that the second mandate of President Biya, who has been in power since 1982, was due to terminate in 2011. That did not happen.

Instead, on 31 December 2007, in his annual New Year message to the nation, President Biya announced his intention to submit to parliament a Bill proposing to eliminate the presidential term limit enshrined in article 6(2) of the 1996 Constitution. ${ }^{17}$ In his message, he alluded to his decision being motivated by a desire to act in consonant with popular demands for his continued leadership. The government and the ruling party exceptionally went to great lengths to justify the proposed constitutional amendments. They echoed the frequently cited argument that it was undemocratic to impose term limits, as that constrained electoral choice (it deprived the electorate of a candidate for the position). ${ }^{18}$ Moreover, they argued that it was essential to preserve and reinforce political and social stability in Cameroon, although they did not explain how. ${ }^{19}$ The opposition vigorously countered these arguments, emphasizing their detrimental effects on the political environment. They highlighted the undemocratic nature of the amendments and noted that it constituted a deception on the electorate, adding that the government could not initiate an amendment of a constitution that resulted from cross-party negotiations. ${ }^{20} \mathrm{~A}$ member of the ruling party who opposed the amendment and later resigned from the party stated that the idea of maintaining one person in power is not good for our country and is not democratic. If this project is adopted, it will take us back 200 years.' $^{21}$

The reaction from the public (who purportedly inspired the proposed amendment) was no less sympathetic. The proposed amendments were introduced at a time when the population faced increasing hardship orchestrated by escalating cost of living, low wages, high unemployment and particularly high youth unemployment, and increased fuel prices. The combined effect of the president's announcement and the prevailing economic conditions sparked massive demonstrations in five major regions in Cameroon. The government reacted with disproportionate force, deploying the military to crack down heavily on the population. It is estimated that over 100 people were killed while 1,500 were arbitrarily arrested and detained. ${ }^{22}$ Private media outlets and press

\footnotetext{
${ }^{16}$ Freedom House, 'Freedom in the World 2010 - Cameroon' (3 May 2010). Available at: <https:// www.refworld.org/docid/4c0ceafec.html>.

${ }^{17}$ France 24 News, 'Cameroon Parliament Extends Biya's Term Limit', 11 April 2008. Available at <https:// www.france24.com/en/20080411-cameroon-parliament-paul-biya-term-limit-extension>.

${ }^{18} \mathrm{Ibid}$

${ }^{19}$ Ibid.

${ }^{20}$ Tansa Musa, 'Update - 1: Cameroon's Biya Signs Law Allowing Third Term Bid', Reuters, 16 April 2008. Available at: <https://www.reuters.com/article/cameroon-constitution-idUKL1529602420080415>.

${ }^{21}$ Royono, 'Cameroon 2011 Presidential Elections - Hon Ayah Paul to Run for Presidential Post', Cameroon Today, 16 December 2010, Available at: <http://news.cameroon-today.com/cameroon-2011presidential-elections-hon-ayah-paul-to-run-for-presidential-post/2648>.

${ }^{22}$ Freedom House, 'Freedom in the World 2010 - Cameroon'.
} 
organizations that broadcasted or published negative reviews of the proposed amendments were suspended or banned.

In spite of popular discontent and fierce opposition from members of opposition parties represented in parliament, the Bill was adopted with a vote of 157 in favour and five votes against. Members of the leading opposition party are reported to have walked out of parliament prior to the vote. ${ }^{23}$ Parliament was heavily militarized on that day and it has been asserted that there were more soldiers than parliamentarians around parliament. The outcome of the voting was predictable because at the relevant time the ruling party, the Cameroon People's Democratic Movement, held 153 of the 180 seats in parliament and there is a very high level of party discipline within the ruling party. Thus Law No. 2008/001 of 14 April 2008, to amend and supplement some provisions of law No. 96/6 of 18 January 1996 (to amend the Constitution of 2 June 1972), was promulgated.

The major innovation that is the thrust of this article is the elimination of the presidential term limit regulated by article 6(2) of the Constitution. The new article 6(2) provides that the President of the Republic shall be elected for a term of office of seven years and shall be eligible for re-election. This is in contrast with the former article 6(2), which provided that the president was re-eligible just once. The first question to be addressed in this article is whether the amendment was constitutional. To answer that question, the focus will be on article 6(2); it would be necessary to revisit the debate on presidential term limits in order to establish a theoretical basis for the position adopted in this article with regard to Cameroon. The article then considers the second question, which hinges on whether the amendment can be considered to be a dismemberment, applying the theoretical framework of dismemberment as conceived by Richard Albert. ${ }^{24}$

\section{An unconstitutional constitutional amendment?}

An assessment of the constitutionality of the term limit amendment requires responding to two pertinent questions: first, whether the amendment was procedurally regular; and second, whether the amendment was substantively regular. The assessment seeks to demonstrate that, while the term limit amendment may be procedurally regular, it may be unconstitutional from a substantive perspective. In the latter case, the analysis will not explore the doctrine of 'unconstitutional constitutional amendment' primarily because that doctrine is premised on the existence of a constituent power. However, in Cameroon - and particularly in the context of the adoption of the 1996 Constitution - the idea of a constituent power is disputable. ${ }^{25}$ Such an inquiry is beyond the scope of this paper. The

\footnotetext{
${ }^{23}$ France 24 News, 'Cameroon Parliament Extends Biya's Term Limit'; Musa, 'Update - 1: Cameroon's Biya Signs Law Allowing Third Term Bid'.

${ }^{24}$ Richard Albert, Constitutional Amendments: Making, Breaking and Changing Constitutions (Oxford University Press, Oxford, 2019) 61; Richard Albert, 'Constitutional Amendments and Dismemberments' (2018) 43(1) The Yale Journal of International Law 1.

${ }^{25}$ Historically, the Cameroonian people have had a limited ability to significantly influence positive political developments in Cameroon. As such, it is doubtful that in practice they can be perceived to some extent as a superior source of political legitimacy, with the power to create a legal order or to constitute political structures. The 1996 Constitution was adopted by what perhaps may be understood broadly as a secondary constituted power or derived constituent power rather than a constituent power (original). From that perspective, one may question the constitutionality of the 1996 Constitution itself. The same questions arise in relation to the method of adoption of the 1972 Constitution, which was subsequently amended extensively as the 1996 Constitution. For more analysis on the concepts of constituent and constituted
} 
analysis will instead focus on the procedural requirements for amendments and the substantive limits of amendments as stipulated in the Constitution.

\section{Procedural regularity}

An analysis of the constitutionality of amendments must begin from an overview of the normative requirements for amending the Constitution as dealt with in article 63 of the Constitution. Article 63(1) provides that amendments to the Constitution can be proposed by the President of the Republic or by parliament and, in the latter case, where a proposal is made by a member of parliament (MP), article 63(2) states that the proposed amendment must be signed by two-thirds of the members of either the National Assembly or Senate. Article 63(3) provides further that both Houses shall meet in congress to examine a draft or a proposed amendment and an amendment shall be adopted by an absolute majority of MPs. Where the President of the Republic requests a second reading, an amendment shall be adopted by a two-thirds majority.

As noted previously, the amendments were proposed by the President of the Republic, and were therefore in compliance with article 63(1). The adoption process also met the normative requirements as the proposed amendments went through the required committee debates and were adopted following a vote of 157 in favour and five votes against. Thus, procedurally, it may be said that the process was in compliance with the normative requirements under article 63.

\section{Substantive regularity}

Whether the amendments were substantively regular is a question for a more complex debate as the Constitution provides no substantive limits on amending the term limit provision. So the question is whether the term limit provision can be interpreted broadly to fall within the eternity provision in article 64, which states:

No procedure for the amendment of the Constitution affecting the republican form, unity and territorial integrity of the state and the democratic principles ${ }^{26}$ which govern the Republic shall be accepted.

The focus in this article is on the last category, the 'democratic principles'. It is not clear what constitutes the 'democratic principles' contemplated by article 64. The Constitution does not make this apparent and there is no known case law in Cameroon providing insights as to the intention of the legislator. Nevertheless, this issue can be assessed more broadly by first examining the democratic credentials of terms limits.

\section{Term limits and democracy}

As discussed earlier, term limits are an increasingly important feature in democratic and non-democratic societies, whether by their adoption in a constitution or by their repeal.

powers, and their role in constitution-making and powers of constitutional amendments, see Yaniv Roznai, 'Unconstitutional Constitutional Amendments: The Migration and Success of a Constitutional Idea' (2013) 3(61) The American Journal of Comparative Law 557, 664-65.

${ }^{26}$ Author's emphasis. 
Alexander Baturo and Robert Elgie argue that 'democracy and binding term limits generally travel together' ${ }^{27}$ A major contention advanced in favour of term limits is its contribution to the liberalization and democratization of political regimes. ${ }^{28}$ On that view, term limits are deemed to provide scope for political competition, thus opening up the political horizon to alternative political parties. ${ }^{29}$ Where elections are contested particularly in the absence of an incumbent - it allows for alternation of both political parties and individual leaders. By contrast, an incumbent eligible for re-election indefinitely might prevent or discourage other candidates from seeking that position. Empirical evidence suggests that in the majority of countries where constitutional amendments have successfully altered presidential term limits, the incumbent has won subsequent election. ${ }^{30}$ This is indicative of the constraints on political competition, particularly given the numerous advantages inherent in incumbency. ${ }^{31}$

It has also been argued that the numerous potential effects associated with incumbency advantage are diminished by the imposition of term limits. ${ }^{32}$ For instance, it is contended that incumbency advantage potentially leads a regime to descend into tyranny. ${ }^{33}$ An incumbent, being in better possession of knowledge of the internal system and its governance, develops the tendency to exact compliance from the electorate. This inclination in turn leads to a cyclical pattern of compliance and retribution for defiance, and subsequently tyranny. ${ }^{34}$ The proposition is that term limits facilitate the ousting of leaders before that cyclical pattern is developed, thereby preventing a regime from descending into tyranny.

Associated with the tendency towards tyranny is the view that incumbency pre-empts the development of real competition and subsequently the lack of accountability by an incumbent. This is predominantly the case in electoral authoritarian regimes where political competition is not 'real'. ${ }^{35}$ The failure to face real challenges to political office leads a leader to lose the inclination to act in the public interest as the stakes of being held accountable through elections are very low. Thus, features of bad governance - such as tyranny and corruption - are prone to develop in the absence of electoral imperatives. That proposition has been countered by opponents of term limits, whose opposition hinges mainly on the public choice theory by virtue of which the electorate's choice to

\footnotetext{
${ }^{27}$ Alexander Baturo and Robert Elgie, 'Presidential Term Limits' in Alexander Baturo and Robert Elgie (eds), The Politics of Presidential Term Limits (Oxford University Press, Oxford, 2019) 1.

${ }^{28}$ Alexander Baturo, 'The Stakes of Losing Office: Term Limits and Democracy' (2010) 40(3) British Journal of Political Science 635, 637.

${ }^{29}$ Maltz, 'The Case for Presidential Term Limits' 131-35; Ginsburg, Melton and Elkins, 'On the Evasion of Term Limits' 1820.

${ }^{30}$ Maltz, 'The Case for Presidential term Limits' 134; Marc Howard and Philip Roessler, 'Liberalising Electoral Outcomes in Competitive Authoritarian Regimes' (2006) 50(2) American Journal of Political Science 365. See also Rosalind Dixon and David Landau, 'Constitutional End Games: Making Presidential Term Limits Stick' (2020) 2(71) Hastings Law Journal 359, 367.

${ }^{31}$ Baturo, 'The Stakes of Losing Office' 638; Nic Cheeseman, 'African Elections as Vehicles for Change', (2010) 21 Journal of Democracy 139, 145-46.

${ }^{32}$ Dixon and Landau, 'Constitutional End Games'145-46.

${ }^{33}$ Andrea Cassani, 'Autocratisation by Term Limit Manipulation in Sub-Saharan Africa' (2021) 55(3) Africa Spectrum 228, 230-33.

${ }^{34}$ Simon Bolivar saw this as the origin of tyranny, although once in office he contravened this view on the misguided opinion that it would promote political stability. Discussed in John Carey, 'The Re-election Debate in Latin America' (2003) 45(1) Latin American Politics and Society 119, 121.

${ }^{35}$ Howard and Roessler, 'Liberalising Electoral Outcomes' 365.
} 
re-elect a popular leader is constrained. This is based on the premise that unpopular leaders can always be voted out without the need to restrict their term in office. This point was emphasized in U.S. Term Limits v. Thornton, ${ }^{36}$ where the US Supreme Court considered that it was contrary to the fundamental principles of America's representative democracy to constrain the people's choice to choose their leaders as the people can always exercise the right to vote them out of office if dissatisfied with their leadership. ${ }^{37}$ It must be noted, however, that the underlying assumption here is based on an efficient electoral system in which elections can be fairly and consistently challenged and incumbents can indeed be voted out where they cease to act in the public interest. The argument fails where the electoral system provides restricted avenues for genuinely fair competition. In the latter situation, the electoral system may be used to entrench incumbency advantages, hence perpetuating undemocratic practices. Moreover, other constitutional limits, notably those related to eligibility criteria for presidential candidacy, can be considered eliminatory in the sense that those who do not meet the criteria are necessarily eliminated from the competition process. ${ }^{38}$

Fundamental to arguments on the democratic credentials of term limits is the contention that the absence of term limits promotes stagnation in politics and governance. Claire Wilmot notes, for instance, that term limits facilitate turnover, which is necessary for democracy to develop. ${ }^{39}$ Incumbents with little electoral incentives are less inclined to develop new policies geared towards addressing issues affecting the societies they govern. The absence of electoral imperatives also promotes little interest in augmenting on the performance of existing institutions or infrastructure. As governance stagnates and the incumbent continues to accumulate power, opposition becomes enfeebled and ultimately fragmented, thereby depriving the society of a fundamental feature of democracy. Similarly, the absence of electoral imperatives may foster a culture of corruption, self-rule and eventually tyranny. ${ }^{40}$ It may be argued, on the other hand, that leaders at the end of their tenure may tend to be less accountable due to the knowledge that they are ineligible for reelection. What must be considered is the accountability mechanisms in existence at any time. So it is likely that the accountability mechanisms may pre-empt such leaders from acting recklessly, as they may be made accountable either while in office or after they leave office.

The trajectory of presidential term limits in constitutional developments and practices in Africa provides an indication of the relative significance of term limits to democracy. As noted earlier, the turning point in these developments may be located in the 1990s, where post-1990 constitutions featured presidential term limits. According to Kristin McKie, two-thirds of all African countries with a semi-presidential system of government included presidential term limits in their constitutions. ${ }^{41}$ Prior to this period, only a few African constitutions contained presidential term limit provisions. Nevertheless, political transition was often achieved not by reference to the constitution, but rather through

\footnotetext{
${ }^{36}$ U.S. Term Limits v. Thornton, 512 U.S. 1286 (1994).

${ }^{37}$ Ginsburg, Melton and Elkins, 'On the Evasion of Term Limits' 1823.

${ }^{38}$ Baturo and Elgie, 'Presidential Term Limits' 5.

${ }^{39}$ Claire Wilmot, 'Why and How Term Limits Matter', 5 October 2015. Available at: <https://africanargu ments.org/2015/10/05/how-and-why-term-limits-matter>.

${ }^{40}$ Baturo and Elgie, 'Presidential Term Limits' 6.

${ }^{41}$ Kristin McKie, 'The Politics of Institutional Choice Across Sub-Saharan Africa: Presidential Term Limits' (2017) 52(4) Studies in Comparative International Development 436, 439.
} 
coups d'état or following the death of a lifetime president. ${ }^{42}$ The widespread recognition of presidential term limits post-1990 stemmed partly from the need to demonstrate a break with less democratic means of governance and power alternation, and was particularly due to an active involvement of the opposition and the civil society in political transitions. A significant number of the constitutions that introduced term limits were negotiated through inclusive processes such as national conferences with active participation from opposition parties. ${ }^{43}$ These events indicated a certain consciousness of the relevance of presidential term limits in harnessing the democratic transition. ${ }^{44}$

The view of term limits as a feature of democracy can also be gleaned from the perspective of some regional and international institutions. The African Union's normative and institutional framework on democracy and constitutional governance can be instructive in discerning the democratic qualities of term limits, particularly with reference to its approach to the concept of 'unconstitutional changes of government'. ${ }^{45}$ Although the concept does not explicitly refer to constitutional amendments eliminating term limits, implicit manipulation of term limit provisions to extend an incumbent's hold on power appears to be a practice that is unacceptable from a democratic perspective and may constitute an unconstitutional change of government in the context of the African Charter on Elections, Democracy and Governance. ${ }^{46}$ This is particularly so where such changes are deemed to be devoid of legitimacy emanating from oppressive practices and human rights violations intended to stifle popular opposition to the amendments. ${ }^{47}$ The African Peer Review Mechanism of the African Union also appears to be supportive of term limits as a necessary feature in embedding democracy in African states. ${ }^{48}$ Beyond Africa, the Venice Commission similarly adopts a positive view towards term limits. In a 2018 report on term limits, it stated that it had taken a positive view to limiting the mandates of presidents and that the regular change of power was a mechanism for preventing the over-concentration of power in a president. ${ }^{49}$ It has further opined that explicit constitutional limitations on successive presidential terms are 'particularly important in countries where democratic structures and their cultural presuppositions have not yet been consolidated'. ${ }^{50}$ The Commission was critical of constitutional amendments in Azerbaijan to eliminate presidential term limits, which were considered 'to be a serious set-back on Azerbaijan's road to a consolidated democracy'. ${ }^{51}$

\footnotetext{
${ }^{42}$ Grauvogel and Heyl, 'The Study of Term Limits in Sub-Saharan Africa' 217.

${ }^{43}$ Ibid 217.

${ }^{44}$ Denis Tull and Claudia Simons, 'The Institutionalisation of Power Revisited: Presidential Term Limits in Africa' (2017) 52(2) Africa Spectrum 79, 80.

${ }^{45}$ See the African Charter on Elections, Democracy and Governance, article 10(2), 23(5).

${ }^{46}$ Christina Murray and Micha Wiebusch, 'Presidential Term Limits and the African Union' (2019) 63(S1) Journal of African Law 131, 147-50.

${ }^{47}$ Ibid.

${ }^{48}$ Ibid 152-53.

${ }^{49}$ European Commission for Democracy Through Law (Venice Commission), Report of Term-limits. Part $1-$ Presidents, adopted by the Venice Commission at its $114^{\text {th }}$ Plenary Session, Study no. 908/2017, CDL-AD (2018)010 (Venice, 16-17 March 2018) 11. Available at: <https://www.venice.coe.int/webforms/documents/ default.aspx?pdffile=CDL-AD(2018)010-e>.

${ }^{50}$ European Commission for Democracy Through Law (Venice Commission), 'Opinion on the Draft Amendment of the Constitution of the Republic of Azerbaijan'. Adopted by the Venice Commission at its $78^{\text {th }}$ Plenary Session' Opinion no. 518/2008 - CDL-AD(2009)010 (Venice, 13-14 March 2009) 5. Available at: <https:/www.venice.coe.int/webforms/documents/default.aspx?pdffile=CDL-AD(2009)010-e>.

${ }^{51}$ Ibid.
} 
From the above arguments, it can be deduced that term limits possess democratic credentials that are essential to securing and entrenching democratic governance. Of course, this correlation must be treated with caution as term limits alone cannot create democracy. Devra Moehler and Steffan Lindberg suggest that the democratic effects of term limits are more feasible when other conditions exist, ${ }^{52}$ and the effects can often be endogenous to a specific country. This is further confirmed by Philip Reyntjens, who asserts a strong positive correlation between term limit and the quality of democracy. ${ }^{53}$ Countries that have consistently respected term limits have developed more resilient societies and more credible institutions - features integral to democratic development. ${ }^{54}$ What is clear is that the purpose of presidential term limits in contemporary times is 'the prevention of tyranny' - in other words, to 'prevent a president from consolidating power and eroding the existing constraints'. ${ }^{55}$ Tyranny is the antithesis of democracy.

\section{So was Cameroon's constitutional term limit amendment unconstitutional?}

Against the backdrop of the above arguments about the democratic credentials of term limits, the constitutionality of the term limit amendment in Cameroon will now be assessed. In relation to article 64 of the Constitution, despite the absence of a normative understanding of what the 'democratic principles' governing the state entail, the provision can be understood properly from a historical and contextual perspective. In 1990, President Biya embarked on the process of democratization in Cameroon following increasing demands for liberal democracy. Reforms adopted included a corpus of legislation otherwise known as the Liberty Laws, which in essence made provision for democratic rights that previously had been absent. The reforms were followed by the promulgation of the 1996 Constitution, which introduced further democratic institutions to consolidate the democratic transition. Part of that reform package included the introduction of a presidential term limit that was not a feature of the previous 1972 Constitution. Besides its inherent authoritarian structure, the 1972 Constitution did not provide conditions for broad based political participation or open political contestations. While it did not expressly prohibit diversity in the political space, it created conditions that entrenched a single party political system. By 1966, all political parties in Cameroon had been subsumed under the ruling party, the Cameroon National Union (CNU), led by then President Amadou Ahidjo. Cameroon remained a de facto one-party state until the democratic upheavals in the 1990s, when the political space was liberalized following the enactment of the Liberty Laws. President Biya had been in power since 1975, first as vice president under Ahidjo and subsequently, following the latter's unexpected resignation in 1984, as president. The CNU was transformed and renamed the Cameroon People's Democratic Party, still under the tutelage of President Biya, who won the first multi-party presidential election in 1997. The term limit provision introduced in the 1996 Constitution was therefore crucial in demonstrating a commitment to political liberalization and

\footnotetext{
${ }^{52}$ Devra Moehler and Steffan Lindberg, 'Narrowing the Legitimacy Gap: Turnovers as a Cause of Democratic Consolidation' (2010) 71(4) Journal of Politics 1448. Mackie identifies free and fair elections, an independent judiciary and a robust legislature as necessary for term limits to achieve their democratic effects. McKie, 'Politics of Institutional Choice' 436.

${ }^{53}$ Philip Reyntjens, 'The Struggle Over Term Limits in Africa: A New Look at the Evidence' (2016) 27(3) Journal of Democracy 61.

${ }^{54} \mathrm{Ibid} 61$.

${ }^{55}$ Baturo and Elgie, 'What Have We Learned About Presidential Term Limits?' 607.
} 
in allowing genuine political turnover. It was an expression of a commitment to end the domination of one party in politics and to end personal rule by a single long-term president. By introducing term limits as part of a package intended to enhance democracy in 1996, it must be inferred that it was perceived as a key feature of the democratic process. In fact, in opposing the article 6(2) amendment, the opposition revisited the historical purport of its introduction in the 1996 Constitution, adding that eliminating that provision defeated the basic principles at the helm of Cameroon's democracy. ${ }^{56}$ From the preceding statement, it may be inferred that at least a portion of the political actors considered the introduction of term limits at the time as intended to constitute part of the 'democratic principles which govern the Republic'.

By and large, a response to the question regarding the constitutionality of the amendment remains equivocal. One the one hand, it may seem rather obvious that the introduction of term limits was part of the package to consolidate the democratic transition, providing a sense of coherence towards the common goal of establishing democratic governance. On the other hand, it is difficult to place it as one of the democratic principles of governance in Cameroon. As noted previously, while term limits are seen as an essential feature in deepening democracy, they are yet to be clearly established as a principle of democracy. An interpretation by the Constitutional Council would be invaluable in responding to this question. However, at the time of the amendments, the opposition - which was the most likely actor to put that question to the Constitutional Council - did not have the requisite majority to do so. The rules on standing to challenge the constitutionality of laws effectively eliminate any possibility for the parliamentary opposition to challenge proposed constitutional amendments. ${ }^{57}$ The Constitution restricts standing to one-third of the members of parliament and the opposition at the time possessed far less seats than the requisite one-third. ${ }^{58}$ Thus, any attempts at challenging the constitutionality of the proposed amendments would have been futile. It is perhaps partly for that reason that, in spite of their antipathy, the parliamentary opposition did not attempt to formally challenge the constitutionality of the amendment. ${ }^{59}$ Nevertheless, the president of an opposition party (Action for Meritocracy and Equal Opportunity) not represented in parliament attempted to challenge the constitutionality of the amendment and parliament's competence to amend the Constitution. However, this constitutional petition was dismissed for want of standing. ${ }^{60}$ Thus, at best it may seem that the amendment was undemocratic - particularly in the tenuous political context in which it was made and in the light of subsequent democratic

\footnotetext{
${ }^{56}$ See the opposition's counter-proposal to the amendment Bill in Report No. 007/AN/8 on Bill No. 819/PJL/AN (March 2008), Amendment No. 02, Section 6, para 5.

${ }^{57}$ Laura-Stella Enonchong, The Constitution and Governance in Cameroon (Routledge, London, 2021) $157-58$.

${ }^{58}$ The opposition had a total of 27 seats, with some of these parties already co-opted into government with the ruling party. The leading opposition party, which was the most credible and possible challenger, only occupied sixteen seats, and in fact abstained from voting. See Enonchong, The Constitution and Governance 79.

${ }^{59}$ The standing rules also restrict individual access. See Decision No. 01/CCT/CC of 7 June 2021, a recent decision of the Constitutional Council demonstrating that, even in social matters that affect the general population, individuals do not have standing.

${ }^{60}$ See Arrêt $n^{\circ}$ 01/CC du 17 avril 2008, decision of the Joint Benches of the Supreme Court of Cameroon sitting as the Constitutional Council. In 2008 the Constitutional Council had not been created, and therefore the Supreme Court was exercising temporary constitutional jurisdiction as per article 67(4) of the Constitution.
} 
decline resulting in significant part from the authoritarian practices facilitated by extensive executive powers and incumbency advantages.

\section{Constitutional dismemberment and the term limit amendment}

The preceding analysis has demonstrated that a response to the question on the constitutionality of the presidential term limit amendment is inconclusive, but may well be framed as an undemocratic amendment. In this section, the argument is taken further to demonstrate that the change of presidential term limit may arguably be considered as a constitutional dismemberment. To demonstrate that dimension of the argument, this section first provides a conceptual analysis of the doctrine of constitutional dismemberment and then assesses the constitutional amendment and subsequent developments in Cameroon within the framework of the conceptual analysis.

\section{Conceptual analysis}

The concept of constitutional dismemberment was first developed by Richard Albert, who identified some constitutional amendments as 'self-conscious efforts to repudiate the essential characteristics of the constitution and to destroy its foundations'. ${ }^{61}$ To Albert, these are not amendments at all. A distinction is therefore made between constitutional amendments and dismemberments, applying the concepts of correction and elaboration. In that respect, Albert argues that an amendment can be perceived as a 'correction made to better achieve the purpose of an existing constitution'. ${ }^{62}$ Further, an elaborative amendment, as the name suggests, entails a 'larger change' in the sense that it transcends a correctional or repair objective to advance 'understanding of contemporary understandings' of a constitution. In effect, from that perspective an amendment is seen properly as a change in the constitution, which has the effect of either correcting a fault or flaw in the constitution or a change that better elaborates on the understanding of the constitution. ${ }^{63}$ Albert's conception of constitutional amendments is consistent with views of amendments as a form of change that ensures continuity and a sense of coherence, indicating wider support for the purposive role of constitutional amendments.

On the other hand, a dismemberment is a more radical constitutional change - a change that 'is incompatible with the existing framework of the constitution because it seeks to achieve a conflicting purpose' ${ }^{64}$ A dismemberment seeks to unmake a constitution by destroying the fundamental structure of the constitution or altering a fundamental right or a core feature of its identity. The effect of a dismemberment may either enhance or weaken liberal democratic procedures and outcomes. A simplistic distinction between amendment and dismemberment can be expressed by reference to the purpose and outcome of change. An amendment is aimed at enabling the constitution to better

\footnotetext{
${ }^{61}$ Richard Albert, Constitutional Amendments: Making, Breaking and Changing Constitutions (Oxford University Press, Oxford, 2019) 61

${ }^{62}$ Richard Albert, 'Constitutional Amendments and Dismemberments' (2018) 43(1) The Yale Journal of International Law 1, 3.

${ }^{63}$ Albert, 'Constitutional Amendments and Dismemberments' 3.

${ }^{64}$ Albert, 'Constitutional Amendments and Dismemberments' 4; Albert, Constitutional Amendments 61,63 .
} 
achieve its purpose, whereas a dismemberment fundamentally transforms one or more of the core commitments or principles of the constitution. ${ }^{65}$ It is important to note that changes to the constitution understood as dismemberment follow ordinary rules of amendments. As noted earlier, a dismemberment entails fundamental changes to the constitution's structure, its rights or identity. These categories are distinguishable but not necessarily mutually exclusive, as a destruction of one category may affect another category. As Albert notes, 'a dismemberment of a constitution's structure may amount to a dismemberment of its identity'. ${ }^{66}$ The effect of a dismemberment of a constitution's identity may be the 'extinguishment of a core constitutional commitment' ${ }^{67}$ The latter is conceived of as neither a right nor a structure, but it represents a fundamental constitutional value that constitutes part of the foundation of a regime. ${ }^{68}$ Constitutional dismemberment takes as its baseline the current understanding of the constitution and its commitments, and evaluates whether a constitutional change breaks significantly with the commitments or understanding. An example of this type of amendment would be where a transformation establishes a clear break with the way the exercise of power is regulated by the constitution. In that respect, Albert views Brexit as a dismemberment of the United Kingdom's unwritten constitution in the sense that it has destroyed a 'core of the constitution and breathe[d] a new purpose into it'. ${ }^{69}$

An axiomatic question that arises at this point concerns the parameters for identifying a constitutional transformation that amounts to a dismemberment. Three possible assessment criteria are suggested. A transformation can be assessed against the founding constitution; against the normative vision of what should be protected by a constitution; and, finally, against the relevant actors of change and the people at the time the change is made. Albert notes that, of the three, the last criteria is preferred as it avoids problems of disagreements on the original intent of a founding constitution and time sensitivity, and the normativity associated with the first two criteria, respectively. ${ }^{70}$ With regard to the third criterion, a transformation will be assessed on the basis of the 'self-understanding' of the relevant actors at the moment of the proposed change. A difficulty with this criterion is how to reconcile any potential divergence in the self-understanding of the relevant political actors. Politicians do not often agree with the electorates on proposed government policies, and this disagreement often leads to lack of popular support for the policies even where they are eventually adopted - as is often the case. Albert appears to address this point by highlighting that the perception of 'those governed by and operating under the constitution' will determine whether the change is an amendment or a dismemberment. ${ }^{71}$ This view is consistent with the inherent logic of dismemberment, as politicians are reluctant to admit that proposed amendments to a constitution are intended to destroy its essential protections or a fundamental commitment. Thus, the public perception of a transformation bears greater significance in terms of how they perceive the potential outcome of a proposed transformation.

\footnotetext{
${ }^{65}$ Albert, 'Constitutional Amendments and Dismemberments' 30.

${ }^{66}$ Albert, 'Constitutional Amendments and Dismemberments' 39. Albert, Constitutional Amendments, 81-86

${ }^{67}$ Ibid.

${ }^{68}$ Ibid.

${ }^{69}$ Albert, 'Constitutional Amendments and Dismemberments' 37-38.

${ }^{70}$ Albert, 'Constitutional Amendments and Dismemberments' 49.

${ }^{71}$ Ibid 50.
} 


\section{An assessment of the term limit amendment in Cameroon}

The argument in this section is premised on the view that the term limit amendment in Cameroon constituted a break with an essential or fundamental constitutional value or core commitment of the Constitution. As argued previously, the term limit provision was introduced as part of a package of democratic reforms intended to symbolize the transformation from an authoritarian state under the 1972 Constitution to a modern democratic state. The 1996 Constitution was the epitome of progressive legislative measures adopted since the 1990s in pursuance of the new democratic vision. Articles $1(2), 2,3$ and 64 reflect the vision of democracy underlying the Constitution. ${ }^{72}$ According to Charles Fombad, they 'underline the democratic nature of the regime', which is 'a matter on which previous Constitutions had either been vague or silent'. ${ }^{73}$ These explain why political opposition parties perceived the term limit amendment to be a betrayal of the population. ${ }^{74}$ Moreover, the uncharacteristic (at the time) overt reaction of the population was indicative of their absolute disapproval of the amendment. To them, it appeared to be a breach of the social contract by which they had agreed to end civil disobedience in the 1990s in exchange for progressive democratic outcomes. That compromise was the result of the Yaoundé Declaration, signed by political parties and the government following a tripartite conference convened by President Biya in 1991 under pressure from the political opposition. ${ }^{75}$ The tripartite conference consisted of representative of the political opposition, the government and 'influential ${ }^{76}$ personalities. The conference was convened to deal with the upheavals occasioned by the declaration of civil disobedience campaigns proclaimed by opposition political parties. ${ }^{77}$ One of the agreements from the Yaoundé Declaration was the opposition's call to end the civil disobedience campaign with a simultaneous commitment by delegates at the tripartite conference to establish a representative constitutional review committee to draft proposals for constitutional reform. Two successive committees were eventually established to draft a new constitution, although in the end President Biya appointed a third and final committee, which ultimately oversaw an extensive revision of the 1972 Constitution. ${ }^{78}$ Nevertheless, it was apparent during the various committee discussions and the period leading to the 1996 Constitution that the idea of 'alternation of power' ${ }^{79}$ preoccupied opposition political parties, and that was eventually reflected in the term limit provision. The violent upheavals in 2008 that preceded President Biya's proposal to amend the term limit provisions indicate that the self-understanding of the populations governed by and

\footnotetext{
${ }^{72}$ Article 1(2) describes Cameroon inter alia as a 'democratic' state which respects traditional values 'that conform to democratic principles'. Article 2 describes Cameroon's features of representative democracy, whilst article 3 refers to the role of political parties in civic education and their obligation to 'respect the principles of democracy'. Article 64 has already been discussed and the essential point here is that it makes Cameroon's principles of democracy unamendable.

${ }^{73}$ Charles Fombad, Constitutional Law in Cameroon (Wolters Kluwer, Amsterdam, 2012) 37.

${ }^{74}$ Musa, 'Update - 1: Cameroon's Biya Signs Law Allowing Third Term Bid'.

${ }^{75}$ Fombad, Constitutional Law in Cameroon, 29-30.

${ }^{76}$ It is worth noting that although these personalities were designated as independent, they had various affiliations with the government and the ruling CPDM party.

${ }^{77}$ Fombad, Constitutional Law in Cameroon 29-30.

${ }^{78}$ ibid.

${ }^{79}$ National Democratic Institute for International Affairs, 'Democratisation in Cameroon: National Delegation Report, October 1991' p. 7. Available at <https://www.ndi.org/sites/default/files/059_cm_demo cratization.pdf>
} 
operating under the Constitution was that the amendment represented a fundamental departure from the democratic project embarked on in the 1990s for which the Constitution was a significant foundation anchoring democracy. The Constitution itself places democracy in an esteemed position, given that article 64 expressly declares the unamendability of the democratic principles by which the country is governed, confirming its supra-constitutionality.

In analysing the nature of term limit amendments, it is important to consider the context in which they occur. Baturo and Elgie affirm that term limit amendments are always constitutional events, and therefore it is important to place those events in context, teasing out the underlying motivations for the change'. ${ }^{80}$ The context in which the term limit was altered in Cameroon also strengthens the contention that it constituted a dismemberment. Two principal reasons are offered below.

First, it was made alongside other amendments, which had the effect of eroding presidential accountability. For instance, the provision on the impeachment of the President was altered. Previously, the president could be tried by the Court of Impeachment for conspiracy against the security of the state. The new position, according to article 53(1), is that he can only be tried for treason. Further, the new article 53(2) provides that the President can only be indicted by the National Assembly and the Senate deciding through an identical vote by open ballot and by a four-fifths majority of their members ostensibly an almost impossible majority to obtain. Moreover, as argued by the opposition MPs, an open ballot has the effect of stifling free choice in voting for the impeachment of the president. ${ }^{81}$ That is even more so in the case of MPs of the ruling party, from whom party discipline is expected and where an attempt to go against party lines may be perceived as rebellion. Again, the Court of Impeachment is yet to be created and there is currently no other institution exercising temporary jurisdiction, so it is practically impossible to impeach the president. In addition to the above mechanisms for abdication of accountability, the president was granted life immunity from prosecution through article 53(3), which provides that acts committed by the President of the Republic in the exercise of his functions shall be covered by immunity and he shall not be accountable for them when he leaves office. While immunity provisions are not undemocratic per se, and in fact can be a mechanism for persuading overstayers to quit, life immunity has the distinct disadvantage of promoting unaccountable governance. ${ }^{82}$ It can be deduced from the nature of these transformations that the overall implicit objective of the government was to further entrench presidential dominance, using the amendment procedures for the purpose of autocratization, rather than ensuring coherence and continuity of the democratization process.

Second, despite the argument of the government about its objective of reinforcing political and social stability, its brutal reaction to suppress opposition to the reforms was indicative of the potential negative effect of the change, as it became clear that it would break with the ongoing democratization process. A genuine constitutional amendment process intended to correct a flaw in the constitution or to advance its understanding would ensure some consensus among the relevant actors, such that the self-understanding of politicians is in tandem with the self-understanding of those governed by the constitution. Obviously, this does not imply a complete 100 per cent approval by the population, as this is impossible

\footnotetext{
${ }^{80}$ Baturo \& Elgie, 'Presidential Term Limits' 9.

${ }^{81}$ Enonchong, The Constitution and Governance 50.

${ }^{82}$ Ginsburg, Melton and Elkins 'On the Evasion of Executive Term Limits' 37.
} 
to achieve. But, as noted by Murray \& Wiebush, some constitutional amendments change the social contract in terms of how power is exercised and by whom, requiring that such a change should be anchored on a broad-based consensus. ${ }^{83}$ Broad-based consensus is understood in this instance not to imply unanimity, but rather a requirement for transparency, the provision of public information and education, and the establishment of special processes to ensure that the views of the public are well considered and debated in proposed significant constitutional amendments. ${ }^{84}$ The government of Cameroon failed to do any of these. Instead, it brutally repressed opposition - a process that in itself is a betrayal of the democratic ideals it purportedly intended to enhance.

Further support for the contention that the term limit alteration constituted a dismemberment can be gleaned from an analysis of subsequent developments in political governance and the democratic space. The purpose of the analysis is to demonstrate the accelerated rate of democratic decline due in significant part to incumbency advantages, single party domination and the life presidency of a constitutionally facilitated authoritarian executive. This is demonstrated in the electoral outcomes of presidential elections where the incumbent has won overwhelming victories since the elimination of the term limit provision. ${ }^{85}$ Various incumbency advantages have facilitated the incumbency victories. The incumbent has been in power since 1982, and thus has a major advantage over the opposition in the internal workings of the political system. It controls and manipulates the electoral machinery to its advantage, utilizes public funds to buttress its political and electoral agenda and controls the instruments of power. One of the reasons expressed by the political opposition against the elimination of term limits was that electoral manipulations have become a well-known phenomenon in Africa, and Cameroon in particular. ${ }^{86}$ As a result, elections no longer constitute an expression of the sovereign will of the people. The incumbent's use of government machinery, particularly control of the instruments of force, has proved formidable in consolidating the incumbent's ascendancy and weakening opposition of any form. Members of political opposition parties, journalists and students have been consistently silenced through repressive measures employed by security forces. ${ }^{87}$ The most recent manifestations of executive repression of opposition include the arbitrary detention of Maurice Kamto, the opposition political leader who alleged himself to be the actual winner of the 2018 presidential election, and the arbitrary detention of journalists from private media outlets for reporting on the 2018 presidential election and the current secessionist armed conflict that has engulfed the North West and South West regions of Cameroon. ${ }^{88}$ In addition to silencing the civil society, the incumbent has successfully fragmented opposition parties by co-opting some of its senior members into accepting cabinet positions in the government. ${ }^{89}$ The overall effect has been the inability of the civil society and opposition

\footnotetext{
${ }^{83}$ Murray and Wiebusch, 'Presidential Term Limits and the African Union' 143.

${ }^{84}$ Ibid.

${ }^{85}$ The victory of the incumbent political party is not limited to presidential elections. Legislative elections have been similarly dominated by the ruling CPDM party. See table on legislative electoral outcomes in Enonchong, The Constitution and Governance 79.

${ }^{86}$ Report No. 007/AN/8 on Bill No. 819/PJL/AN (March 2008), Amendment No. 02, Section 6, para 4.

${ }^{87}$ Enonchong, The Constitution and Governance 220.

${ }^{88}$ These issues have been well captured in Bertelsmann Stiftung, 'Bertelsmann Transformation Index: Cameroon Country Report 2020'. Available at: <https://www.bti-project.org/en/reports/country-reportCMR-2020.html\#pos4>.

${ }^{89}$ Ibid; see in particular the section on 'Stability of Institutions'.
} 
parties to coalesce to provide a viable challenge to the status quo. The elimination of term limits has ensured the persistence of these conditions, and meaningful democratic competition or rotation of power is impossible as long as the current leadership - with its unfair incumbency advantages - continues to contest elections. The situation depicted above is consistent with the literature on term limits, democracy and incumbency advantages discussed previously. ${ }^{90}$

Underlying the difficulties arising from incumbency advantages are constitutional structures that have failed to buttress the democratic transition. The institutions that might otherwise constrain executive power are fragile and depend largely on the president for their survival. The judiciary, for instance, is subordinate to the executive, in particular the president, and depends on the president for its independence. ${ }^{91}$ The control exerted by the executive on the judiciary has undermined the latter's ability to constrain executive abuse of power and the violation of human rights. The impotence of the judiciary has resulted in the loss of its social legitimacy, and has perpetrated the stagnation of democracy by its inability to adequately address electoral disputes, hence contributing to the survival of the status quo. The 1996 Constitution made provision for a Constitutional Council to manage electoral disputes relating to legislative and presidential elections. This was seen as part of the fabric of the democratization process. That institution was not established until 2018, shortly before the presidential election of that year. The delay in its establishment is due to the failure of the president and parliament to initiate the necessary legislative process. However, the institution was instrumental in confirming President Biya's victory in the 2018 election despite evidence of gross electoral malpractices, which marred the credibility of the elections. ${ }^{92}$ The Constitutional Council has since established itself as part of the fabric to enhance presidential dominance, rather than promoting the democratic process. One reason for the timidity of that institution is its dependence on the president, who has an influential role in the appointment and dismissal of the 'judges', ${ }^{93}$ a factor that undermines its independence. ${ }^{94}$

For its part, the legislature - which is equally dependent on the executive - has been unable to exercise any meaningful constraints on the latter. The ruling party has maintained an overwhelming majority in parliament and has facilitated the adoption of legislation proposed by the executive without satisfactory levels of scrutiny. In the same vein, it has obstructed reform Bills initiated by the opposition. Besides the control obtained through its superior representation in parliament, the president can dissolve parliament on his initiative on the basis of 'a serious crisis', ${ }^{95}$ a criterion that is undefined and provides a basis for dissolution of an errant parliament. Thus, rather than exercise

\footnotetext{
${ }^{90}$ Maltz acknowledges the likelihood of such outcomes from incumbency advantages. See Maltz, 'The Case for Presidential term Limits' 139.

${ }^{91}$ Constitution of Cameroon, art 37(3) provides that he is the guarantor of the independence of the judiciary, and in that respect he is assisted by the Higher Judicial Council, which provides an opinion on appointments, promotion and discipline to the president. Ironically, the president chairs the HJC, which is meant to advise him.

${ }^{92}$ Aly Verjee and Jude Mutah, 'Cameroon's Governance Crisis Continues' (US Institute for Peace, 17 December 2018). Available at <https://www.usip.org/publications/2018/12/after-election-cameroonsgovernance-crisis-continues $>$.

${ }^{93}$ Given that the Constitutional Council is not a court, the judges are referred to as members.

${ }^{94}$ Details of this unsatisfactory institutional design have been discussed in Enonchong, The Constitution and Governance, 149-152, 162-166 and Charles Fombad, 'The New Cameroonian Constitutional Council in a Comparative Perspective: Progress or Retrogression? (1998) 42(2) Journal of African Law 180.

${ }^{95}$ Constitution of Cameroon, art. 15(4).
} 
oversight of the executive, it is in the interest of parliament to ensure that the goals of the executive are enhanced irrespective of any potentially adverse effect on democracy in Cameroon. It is therefore unsurprising that the Bill to amend the term limit provision received overwhelming votes from the ruling party, irrespective of the broad resistance from the public that they purportedly represent.

Admittedly, the presence of a term limit provision by itself is not sufficient to embed democracy. As noted in the preceding paragraphs, some institutional structures that should contribute to democratic progress are themselves fragile. Nevertheless, for that reason it is important that constitutional amendments seek to correct these 'flaws' in order to keep the democratization agenda on track. The elimination of the term limit provision definitely detracted from that agenda, whereas its continued existence would have provided an opportunity for political party alternation. While there is no guarantee that the ruling party would have lost the election, it would have provided the opportunity for a change of leadership at the top and opportunities to revert to a genuine democratization process. The absence of electoral imperatives has diminished actual political will to improve existing democratic institutions. Term limit provisions are important, particularly in fragile democracies where political power is concentrated in a single institution or person without sufficient or robust accountability mechanisms. As Cameroon has demonstrated, in such a situation longevity in power provides the platform for the use of various incumbency advantages to maintain political dominance, with the attendant effect of undermining democratic developments. In the light of the above discussion, it is evident that the absence of a presidential term limit has contributed significantly to a stalled democratization process. The effect of the term limit elimination resulted in a break with a core constitutional commitment to democratic development.

\section{Reflecting on constitutional amendments rules in Cameroon}

One prominent issue highlighted by the term limit amendment is the relative ease with which the Constitution can be amended in Cameroon. Besides the eternity provision in article 64, the legislator has absolute freedom to amend the provisions of the Constitution. There is no variation of amendment rules in terms of the significance of the constitutional provision, nor is there a different procedure or qualified majority for amending constitutional provisions and ordinary legislation. This raises the question of whether the normative hierarchy of the Constitution is merely symbolic if it can easily be amended, applying the same procedure used to amend ordinary legislation. The Indian Supreme Court has remarkably addressed these issues with respect to the easy amendability of the Indian Constitution through its development and use of the Basic Structure Doctrine. The Court applies the doctrine to justify imposing limits on the amending power of legislators to 'those changes that cohere with the [Indian] Constitution' ${ }^{96}$ - in other words, changes that do not dismantle the basic foundation or structure of the constitution, interpreted as including principles such as constitutional supremacy, the republican and democratic forms of government, the secular character of the state, the separation of powers, and federalism. ${ }^{97}$ More recently, the Kenyan High Court has affirmed the utility of that doctrine and applied it to declare proposed constitutional amendments to be unconstitutional. In David Ndii and Others $v$ Attorney General and Others (more widely known as

\footnotetext{
${ }^{96}$ Albert, 'Constitutional Amendment and Dismemberment' 18.

${ }^{97}$ Kesavananda Bharati Sripadagalvaru v Kerala, (1973) 4 SCC 225
} 
the BBI judgment), ${ }^{98}$ the Court acknowledged that 'there is no clause in the Constitution that explicitly makes any article in the Constitution un-amendable'. ${ }^{99}$ Nevertheless, taking into account a number of factors, including the history of the constitution-making process and the aspiration of the Kenyan people at the time, the Court reasoned that 'some aspects of the Constitution [could] not be changed by ordinary amendment rules'. In particular, the proposed constitutional amendment impinged on the basic structure of the Constitution and could not be accomplished without reverting to the people who were instrumental in 'designing' that basic structure. Further, in language that reflects the conceptual underpinnings of dismemberment, the Court held in reference to the Constitution that it was 'the desire of Kenyans to barricade it against destruction by political and other elites'. ${ }^{100}$ The Court of Appeal has also upheld this decision, noting emphatically that the proposed amendments would constitute a dismemberment of the Kenyan Constitution. ${ }^{101}$

The examples of India and Kenya demonstrate how the courts can be useful in imposing implicit limits on the constitution to protect important constitutional values. In Cameroon, despite the presence of an eternity clause, it may be possible to conceive of circumstances where implicit limits could be imposed on constitutional amendments to protect fundamental constitutional values or core constitutional commitments - for instance, article 1(3) of the Constitution, which entrenches bilingualism. This is not protected by the eternity clause but represents a core commitment and a fundamental value embodying the identity of the Cameroonian people. An amendment of that provision is likely to have a profound impact on the identity of the Cameroonian people, and possibly the political stability of the country. ${ }^{102}$ An attempt to amend that provision should arguably evoke the basic structure doctrine or a similar doctrine aimed at protecting fundamental constitutional values or core commitments that are not protected by an eternity clause. However, there are two important considerations that may need to be addressed to determine the applicability of a basic structure doctrine. The first is the issue of an original constituent power, which as previously noted is an issue that is yet to be clarified in order to establish the validity of the constitutional amendment powers. ${ }^{103}$ This issue alone requires an in-depth investigation, which cannot be undertaken within the limited scope of this article. The second consideration is that of judicial independence. Relying on the basic structure doctrine to protect such constitutional commitments or values may be a tall order, as it relies heavily on the assertiveness of the Constitutional Council. As noted earlier, that institution lacks independence and has been instrumental in validating authoritarian practices. In both India and Kenya, one important factor that has contributed to the courts' decisions is the relative independence of their judiciaries. Although there have been attempts at interfering with the judiciaries, the judges have a

\footnotetext{
${ }^{98}$ David Ndii and Others $v$ Attorney General and Others, Petition No. E282 of 2020.

${ }^{99}$ Para 473.

${ }^{100}$ Pars 473. Author's emphasis.

${ }^{101}$ See a summary of the 'amendment' and 'dismemberment' dimension of the BBI judgment in the Court of Appeal in Richard Albert, 'Kenyan Judges Stop President's Reforms as Attempt to 'Dismember' the Constitution', The Conversation, 24 August 2021, available at: <https://theconversation.com/kenyan-judgesstop-presidents-reforms-as-attempt-to-dismember-the-constitution-166587? > .

${ }^{102}$ The current socio-political crisis, which has morphed into an armed conflict in the English-speaking regions of Cameroon, stemmed from a lack of sufficient recognition of the common law tradition practised in those regions.

${ }^{103}$ Above (n 25).
} 
fairly high level of independence from the executive, which strengthens their ability to resist external pressures.

With specific reference to presidential term limits, the evidence from Africa and Latin America attests to the unreliability of the judiciary when it comes to protecting term limit provisions, irrespective of the nature of the limits to their amenability. In Senegal and Burundi, for instance, the courts were instrumental in legalizing third-term bids despite their parliaments earlier voting down proposed constitutional amendments to eliminate them. ${ }^{104}$ Similarly, the courts in Burkina Faso, Ecuador, Venezuela and Bolivia were used to manipulate term limit provisions, while the unconstitutional constitutional amendment doctrine was used controversially by courts in Costa Rica, Nicaragua, Honduras and Bolivia to eliminate term limit provisions. ${ }^{105}$ The only known instance so far, as documented by Versteeg et al., where a court has successfully halted an attempted term limit amendment, is in Colombia. ${ }^{106}$ President Alvaro Uribe attempted to use the route of a referendum to amend the Constitution to extend the presidential term, which would allow him to serve for a third term. The Colombian Constitutional Court found the proposed amendments to be unconstitutional as they amounted to a substitution of the constitution. According to the Court, such a process could only be carried out by means of a constitutional assembly. As with the Indian and Kenyan courts, the success of the Colombian Constitutional Court has been attributed partly to the independence of the Court. ${ }^{107}$

Despite the potential limits of judicial power to enforce term limit provisions, the absence of differentiated constitutional amendment rules in Cameroon still remains a concern. That absence may fuel suspicions of a deliberate attempt at suppressing the sovereign will. This reverts to the history and context in which the constitution itself was adopted. As discussed previously, the will of the people at the time was a preference for a newly drafted constitution reflecting the mood at the time - democratization, features of modern constitutionalism and a true reflection and respect for the distinct nature of both the inherited English and French cultures, particularly in areas such as education and legal tradition. The call for an inclusive and consultative constitution-making process was thwarted by the executive, with the result that an unrepresentative executive-appointed committee revised the 1972 Constitution extensively to include some features of modern constitutionalism. The absence of the people as the primary constituent power in the 'making' of that constitution was not accidental. It may well be considered a deliberate strategy that has, among many, the consequence of ensuring that the Constitution can be amended quite easily and amendments that have potential significance for issues such as democracy, human rights and the exercise of political power are left entirely in the control of the executive and the legislature.

This position is compounded by the nature of the referendum provision on constitutional amendments. Article 63(4) empowers the president to unilaterally 'decide to submit any bill to amend the Constitution to a referendum'. Whilst this is not unusual,

\footnotetext{
${ }^{104}$ Tull and Simons, 'The Institutionalisation of Power Revisited' 87.

${ }^{105}$ Dixon and Landau, 'Constitutional End Game' 381-82; David Landau, Yaniv Roznai and Rosalind Dixon, 'Term Limits and the Unconstitutional Constitutional Amendment Doctrine' in Alexander Baturo and Robert Elgie (eds), The Politics of Presidential Term Limits (Oxford University Press, Oxford, 2019) 53-74.

${ }^{106}$ Mila Versteeg, Timothy Horley, Anne Meng, Mauricio Guim and Marilyn Guirguis, 'The Law and Politics of Presidential Term Limit Evasion' (2020) 120 Columbia Law Review 173, 217-18.

${ }^{107}$ Dixon and Landau, 'Constitutional End Game' 413.
} 
no other entity - whether a section of the electorate or legislators or territorial entities can initiate a referendum. Moreover, the subject matter of the referendum is determined by the president. Cameroon's approach to constitutional amendments effectively excludes the electorate from determining constitutional provisions, which can be amended through referenda. Perhaps this approach can be explained by the fact that, although sovereignty lies with the people as per the Constitution, national sovereignty can be exercised through the president. ${ }^{108}$ As such, the president may be deemed to be exercising national sovereignty in determining the subject matter of referendum operations. However, this is merely an inference, as the Constitution does not expressly outline the specific questions that can be referred to a referendum. ${ }^{109}$ The Venice Commission's guidelines on referendum operations provide that the legal basis for referendum operations should be clearly outlined at the constitutional level and should include the type of referendum and the subject matter of referenda. ${ }^{110}$ The Constitution of Cameroon nevertheless provides some of these safeguards where the president submits to a referendum, a reform Bill that would normally ${ }^{11}$ fall within the legislative competence of parliament. ${ }^{112}$ In such a case, there is a requirement to consult the presidents of the Constitutional Council and the two houses of parliament, and the specific subject matter is broadly enumerated. ${ }^{113}$ In this specific instance, it is perhaps a recognition of the fact that the president is exercising authority over what should normally be within the legislative competence of parliament. For the purpose of accountability, particularly in the context of the separation of powers à la Camerounaise, the requirement to consult parliament and the Constitutional Council is defensible. Yet the consultation requirement is quite limited as the constitution does not expressly mandate presidential adherence to the decision or recommendation of these institutions. It would seem that ultimately, even where popular influence on proposals for constitutional reform could be exercised indirectly through supposedly elected representatives in parliament, that is practically nonexistent. A well-considered referendum structure is likely to incorporate avenues through which popular participation could be embedded in determining not only the outcome of referendum operations, but in the first instance the substance of constitutional questions to be settled by a referendum. This is not to suggest that a referendum would be the appropriate avenue to protect term limit provisions. The discussion is aimed at highlighting the flaws in the constitutional design of the referendum system, to the extent that they stifle any possible avenues for genuine public participation. Besides, an effective referendum operation would depend on an independent and credible electoral system, with which Cameroon is not currently endowed.

\footnotetext{
${ }^{108}$ Constitution of Cameroon, art. 2(1).

${ }^{109}$ Article 255(2) of the Kenyan Constitution provides a comprehensive list of matters that can be referred to a referendum.

${ }^{110}$ Guidelines for Constitutional Referendums at National Level Adopted by the Venice Commission at its 47th Plenary Meeting (Venice, 6-7 July 2001), para IIA. Available at: <https://www.ohchr.org/EN/Issues/ RuleOfLaw/CompilationDemocracy/Pages/CoEGuidelines1.aspx>.

${ }^{111}$ Parliament is the principal legislative body in Cameroon. However, its areas of legislative competence are clearly outlined in article 26 of the Constitution. Any areas not specifically listed therein fall within the residual legislative competence of the authority empowered to issue rules and regulations (in effect, the executive, primarily the president - article 27).

${ }^{112}$ Constitution of Cameroon, art. 36(1).

${ }^{113}$ ibid.
} 


\section{Conclusion}

Presidential term limits constitute an important feature in the democratic fabric of a country, and their elimination has the potential to undermine democratic developments. This article has demonstrated that in the case of Cameroon, the elimination of the term limit provision was undemocratic. Although it may not be possible to argue incontrovertibly that the amendment was unconstitutional, the article has argued that the events subsequent to the term limit amendment confirm its effect on the rapid democratic decline that has occurred in Cameroon. More particularly, given the core commitment to democracy underlying the 1996 Constitution, the elimination of the term limit resulted in a fundamental break with that commitment. The article has demonstrated that the selfunderstanding of the population governed by the Constitution did not align with that of the government at the time of the change. While the government capriciously argued that it was necessary for political stability, the population and the political opposition perceived this as a 'fraude a la constitution', a betrayal of the vision of democratization that preceded the adoption of the 1996 Constitution. The subsequent democratic decline arising principally as a result of incumbency advantages attests to the fact that the amendment amounted to a constitutional dismemberment, rather than an attempt to correct a flaw in the constitution or to enhance understandings of it.

The above discussion has also demonstrated that protecting presidential term limits in Cameroon, and indeed core constitutional commitments, is important. However, there are no easy solutions for how to do so. Reliance on the Constitutional Council alone is insufficient, as is reliance on the political opposition, which is heavily fragmented and lacking a common vision. Moreover, some opposition political parties are in coalition with the ruling party and the president is chair of the ruling party, which he controls with a firm hand. In addition, there is high party discipline among members of the ruling party. As such, there is little prospect for rebellion within the ruling party that can diminish presidential support to the point of ousting him. Further, reliance on popular protests may also be unrealistic given the characteristic violent and often fatal repression of popular protests, such as the protest that attempted to oppose the term limit amendment itself. In countries such as Mali, Paraguay and Burkina Faso, where popular protests succeeded in preventing term limit circumvention, the success depended on other factors, such as the cooperation of the military, a strong and united civil society and the support of religious institutions. ${ }^{114}$ The problems in Cameroon are many. The military is firmly controlled by the president and extremely loyal to him. Like the political opposition, the civil society is fragmented and frequently subjected to repression by the executive with the assistance of the military. Religious institutions in Cameroon do not have the kind of influence and power necessary to significantly influence political outcomes, as was the case with the Catholic Church in the Democratic Republic of Congo ${ }^{115}$ and Paraguay ${ }^{116}$ and, in any case, they often come under attack from the executive. ${ }^{117}$

\footnotetext{
${ }^{114}$ Versteeg et al, 'The Law and Politics of Presidential Term Limit Evasion' 213-17. See also Filip Reyntjens, 'Respecting and Circumventing Presidential Term Limits in Sub-Saharan Africa: A Comparative Survey' (2020) 119(475) African Affairs 275, 279, 289-90.

${ }^{115}$ Reyntjens, 'Respecting and Circumventing Presidential Term Limits in Sub-Saharan Africa' 279.

${ }^{116}$ Versteeg et al, 213.

${ }^{117}$ While they have become more vocal, they are also divided - and the government plays on this division. See generally, Charles Fombad, 'State, Religion, and Law in Cameroon: Regulatory Control, Tension, and Accommodation' (2013) 57(1) Journal of Church and State 18.
} 
The above situation suggests that, in a country such as Cameroon, preserving presidential term limit provisions may be a complex endeavour that requires myriad factors and concerted action from a broad range of actors. An independent judiciary is a necessity, together with an independent legislature and an independent Constitutional Council that is more accessible to the ordinary citizen. These must exist alongside other conditions such as a robust and united civil society and political opposition. With regard to the military, one must be cautious about their involvement in political affairs as the record of military interventions in other jurisdictions has been mixed. Nevertheless, a military that has respect for human rights and the rule of law would ideally be less inclined to use repression to assist a political leader to pursue undemocratic objectives. How these factors and actors should protect constitutional term limits - or, indeed, fundamental or core constitutional commitments - is unclear. It would be useful to further examine the precise nature of their interaction and the conditions necessary for success.

Cite this article: Enonchong L-S. 2022. Unconstitutional constitutional amendment or constitutional dismemberment? A reappraisal of the presidential term limit amendment in Cameroon. Global Constitutionalism 11: 274-296, doi:10.1017/S2045381721000290 